\title{
Quality Assessment of Some Freshwater Resources Located in Bucharest and Surrounding Areas
}

\author{
II. Water quality assessment of Arges and Dambovita rivers
}

\author{
PETRA IONESCU ${ }^{1,2}$, ALEXANDRU ANTON IVANOV ${ }^{1}$, VIOLETA MONICA RADU ${ }^{1,2 *}$, GYORGY DEAK ${ }^{1}$, ELENA DIACU2*, \\ ECATERINA MARCU ${ }^{1}$, ANA MARIA ANGHEL ${ }^{1}$ \\ ${ }^{1}$ National Institute for Research \& Development in Environmental Protection, 294 Splaiul Independentei, 060031, Bucharest, \\ Romania \\ 2University Politehnica of Bucharest, Faculty of Applied Chemistry and Materials Science, 1-7 Polizu Str., 011061, Bucharest, \\ Romania
}

\begin{abstract}
The water quality assessment of Arges River and its tributary Dambovita River is presented in this paper as second part of an extended study on the evaluation of some freshwater resources quality located in Bucharest and surrounding areas [1]. This case study was carried out mainly for the water in the confluence area of Arges and Dambovita rivers, where a water and sediment sampling campaign was organized in J une 2018. 21 quality parameters were determined for water samples and for the sediment samples the heavy metals content was evaluated. The results of the water samples analysis allowed the framing in quality classes, and for sediment samples the values obtained were compared with the chemical quality standards for sediments, according to the current national regulations. Following the assessment, it was established that the freshwaters in both Arge - River and Dambovita River, downstream the confluence with the Dambovita River are loaded with different pollutants, such as organic substances and nutrients leading to a lower water quality classification.
\end{abstract}

Keywords: freshwater, water quality, pollution, Arges River, Dambovita River

Freshwater is the most important natural resource for life and the environment, nevertheless it is a vulnerable and limited resource, especially due to its irrational exploitation [2-4]. The availability of water in sufficient quantities and of good quality will become even more challenging for Europe in the future due to climate change, the growing needs of the urban population, as well as, industry and agriculture expansion [5-8].

Nowadays, the protection of aquatic life and human life is a permanent concern, so monitoring the quality of surface water has an important role to play $[9,10]$. According to studies in the field, the presence of chemical pollutants in the environment, especially from anthropogenic sources, represents a threat to living organisms [11-13]. Pollutants and potentially toxic elements (like heavy metals) can accumulate in quantities exceeding the maximum admissible limits in both surface and underground waters and soil. The negative effects of pollutants can be expressed both directly on the organisms that populate the respective aquatic basin and indirectly by diminishing oxygenation, changing the $\mathrm{pH}$ and other physical and chemical properties of the water [4]. Among the harmful consequences of these substances we can mention the carcinogenic and mutagenic effects, accumulation in the food chain links, high toxicity etc., all of which contributing to the serious disturbance of the natural equilibrium [1417].

In urban areas, the quality of the aquatic ecosystem is considerably influenced by industrial and agricultural effluents, as well as wastewater collected in the sewage system [18]. In Romania, at the Bucharest Municipality level, the water of Dambovita River is mainly used as drinking water supply. The Dambovita River has a length of $286 \mathrm{~km}$ and is the largest tributary of the Arges River (350 $\mathrm{km})$ [19]. Bucharest Municipality is the main city having significant impact on the two rivers, because a part of the wastewater collected through the sewerage system is discharged into the Dambovita River downstream of its Bucharest course where the sewage treatment plant is located (at Glina point), but due to the wastewater treatment plant incapacity to take over the total collected wastewater volume, the natural regime of the Dambovita River is sensitively modified by the urban influence [20]. Also, the rapid and unplanned expansion of the constructions in the surrounding areas of Bucharest city has caused water supply problems related to the lack of efficient sewerage systems and the emergence of uncontrolled landfills which had a significant impact on the freshwater resources quality. As a consequence, an extended study on evaluation of the freshwater resources quality in some Bucharest and surrounding areas was performed in order to establish the freshwater quality classes in accordance to the provisions of the European Water Framew ork Directive (WFD) 2000/60/EC [21] which has been implemented in Romanian regulations [22].

The Part I of this work related a case study on water quality assessment of the Mogosoaia, Herastrau and Pantelimon Lakes, builton the Colentina River which is the tributary of the Dambovita River [1]. This paper is the Part II which presents the water quality assessment of Arges and Dambovita rivers at their confluence area through the physicochemical parameters according to national current regulations.

\section{Experimental part}

Study area and samples collection

The selected area for this study is situated at the confluence of the Arges River with its tributary, the Dambovita River, included in the Arges-Vedea hydrographic area, south Romania. To achieve the study objective, a 


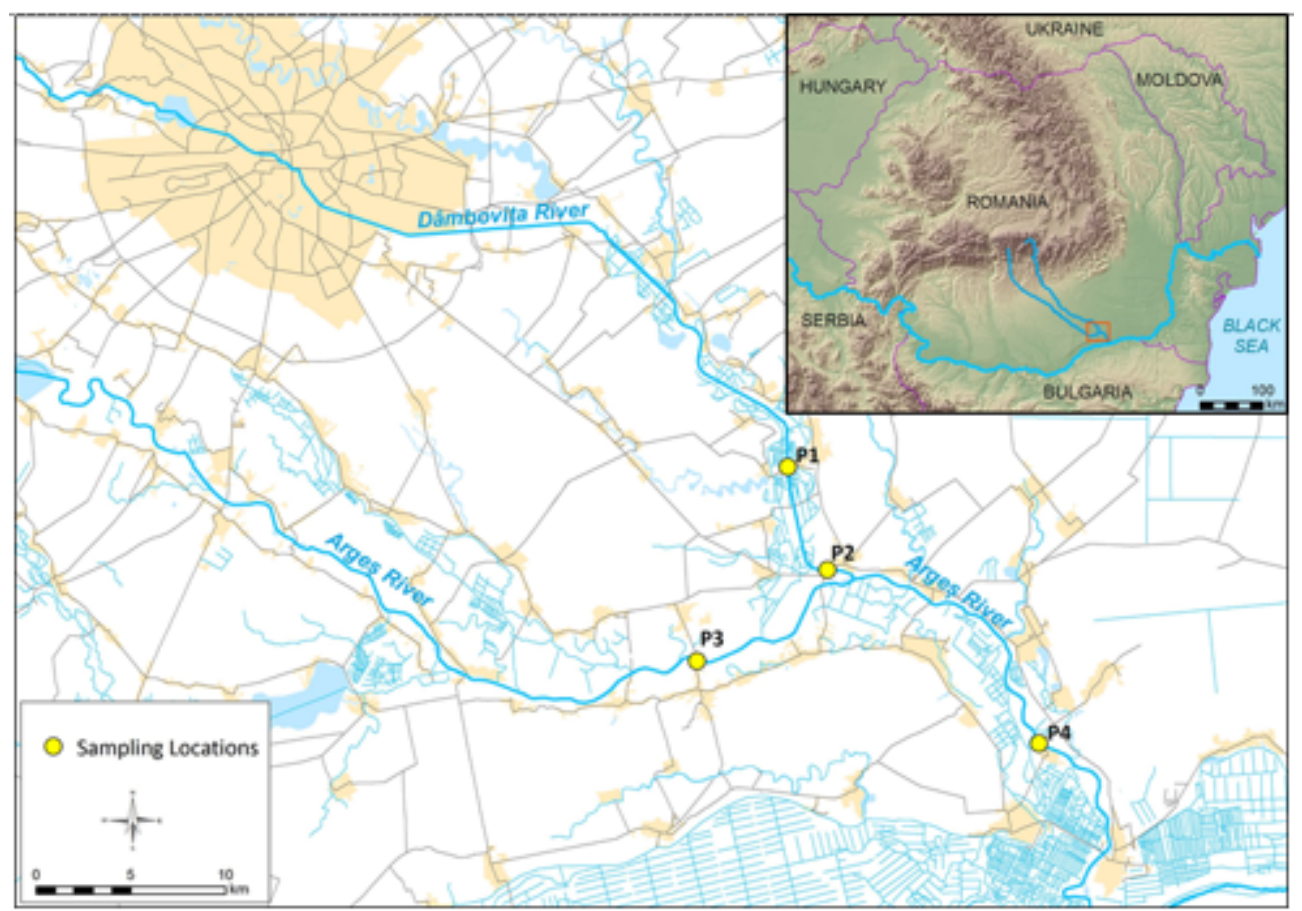

\begin{tabular}{|c|c|c|c|}
\hline \multicolumn{2}{|c|}{ Notation of sampling site locations } & \multicolumn{2}{c|}{ Geographical coordinates } \\
\cline { 3 - 4 } & & Latitude & Longitude \\
\hline Dambovita/Nuci & P1 & $4428116^{\circ} \mathrm{N}$ & $2642888^{\circ} \mathrm{E}$ \\
\hline Dambovita/Budesti & P2 & $4423198^{\circ} \mathrm{N}$ & $2645384^{\circ} \mathrm{E}$ \\
\hline Arges/Hotarele & P3 & $4418984^{\circ} \mathrm{N}$ & $2636657^{\circ} \mathrm{E}$ \\
\hline Arges/Clatesti & P4 & $4414777^{\circ} \mathrm{N}$ & $2659128^{\circ} \mathrm{E}$ \\
\hline
\end{tabular}

water and sediment sampling campaign was organized in J une 2018 on the two mentioned rivers. Figure 1 shows the study area location and Table 1 shows the four sampling locations P1-P4 (P1-Dambovita/Nuci, P2-Dambovita/ Budesti, P3-Arges/Hotarele, P4-Arges/Clatesti) with their geographical coordinates.

The water samples were collected in polyethylene recipients ( $3 \mathrm{~L}$ ) from approximately $30 \mathrm{~cm}$ below water surface and were kept at $4{ }^{\circ} \mathrm{C}$ during their transport to the laboratory, according to the in force standards [23-25]. Sediment samples were collected according to sampling procedure of the current standards [26]. In situ measurements were performed for the determination of unstable parameters: temperature, $\mathrm{pH}$, conductivity and dissolved oxygen using a portable multi-parameter WTW Multi 340i. The device was calibrated using standard solutions before each determination.

\section{The determination of quality parameters}

The following 21 physicochemical parameters were determined for water samples: temperature $(T), p H$, electrical conductivity (EC), turbidity, dissolved oxygen (DO), chemical oxygen demand $\left(\mathrm{COD}_{\mathrm{Cr}}\right.$ and $\left.\mathrm{COD}_{\mathrm{Mn}}\right), 5-$ days biochemical oxygen demand (BOD), total dissolved solids (TDS), chloride ( $\mathrm{Cl}-$ ), sulphates ( $\mathrm{SO}_{4}{ }_{4}^{2-}$ ), ammoniumnitrogen $\left(\mathrm{NH}_{4}-\mathrm{N}\right)$, nitrate-nitrogen $\left(\mathrm{NO}_{3}-\mathrm{N}\right)^{4}$, nitrite-nitrogen $\left(\mathrm{NO}_{2}-\mathrm{N}\right)$, total nitrogen (TN), total phosphorus (TP), orthophosphates $\left(\mathrm{PO}_{4}^{-\mathrm{P})}\right.$, Chlorophyll a $(\mathrm{Chl}$ a), cadmium (Cd), lead (Pb) and copper (Cu).

After reception of the sediments samples in the analysis laboratory, they were air dried at room temperature. After drying, to obtain representative sediments samples, they were milled, sieved and in order to bring them into the
Fig. 1. Location of the study area
Table 1

SAMPLING SITE LOCATIONS solution, mineralization of about $0.5 \mathrm{~g}$ of the sample from the $63 \mathrm{im}$ fraction in the presence of aqua regia has been performed. For the assessment of the sediment quality, the following heavy metals have been determined: cadmium (Cd), mercury $(\mathrm{Hg})$, copper $(\mathrm{Cu})$, nickel $(\mathrm{Ni})$, lead $(\mathrm{Pb})$, chromium $(\mathrm{Cr})$ and zinc $(\mathrm{Zn})$. For heavy metals determination a Atomic Absorption Spectrophotometer ContrAA 700 (Analytikjena) have been used.

All reagents used for the determination of the physicochemical parameters were of analytical purity and the analytical determinations have been performed using standardized methods of analysis.

\section{Results and discussions}

\section{Water quality assessment}

The assessment of the water samples quality collected from sampling locations P1-P4 was carried out following the national regulations, according to which the physical and chemical indicators are grouped as follows: thermal regime and acidification, oxygen regime, nutrients, salinity, specific toxic pollutants of natural origin and other relevant chemical indicators [22].

According to the performed analyses, the $\mathrm{pH}$ values were within the limits specified by M.0. 161/2006 [22] and ranged from 7.36 to $7.99 \mathrm{pH}$ units and the temperature varied within the range $24.5-27^{\circ} \mathrm{C}$.

Figure 2 shows the water quality classes for the georeferenced oxygen regime indicators at the sampling locations of the water samples according to the mentioned order. For DO parameter, the minimum value of $0.8 \mathrm{mgO} /$ $L$ was determined in $P 1$ and the maximum value of 8.00 $\mathrm{mgO}_{2} / \mathrm{L}$ was determined in $\mathrm{P3}$. The $\mathrm{COD}_{\text {values }}$ determined varied in the range $8.77 \mathrm{mgO}_{2} / \mathrm{L}(\mathrm{P} 3)-50.42$ 


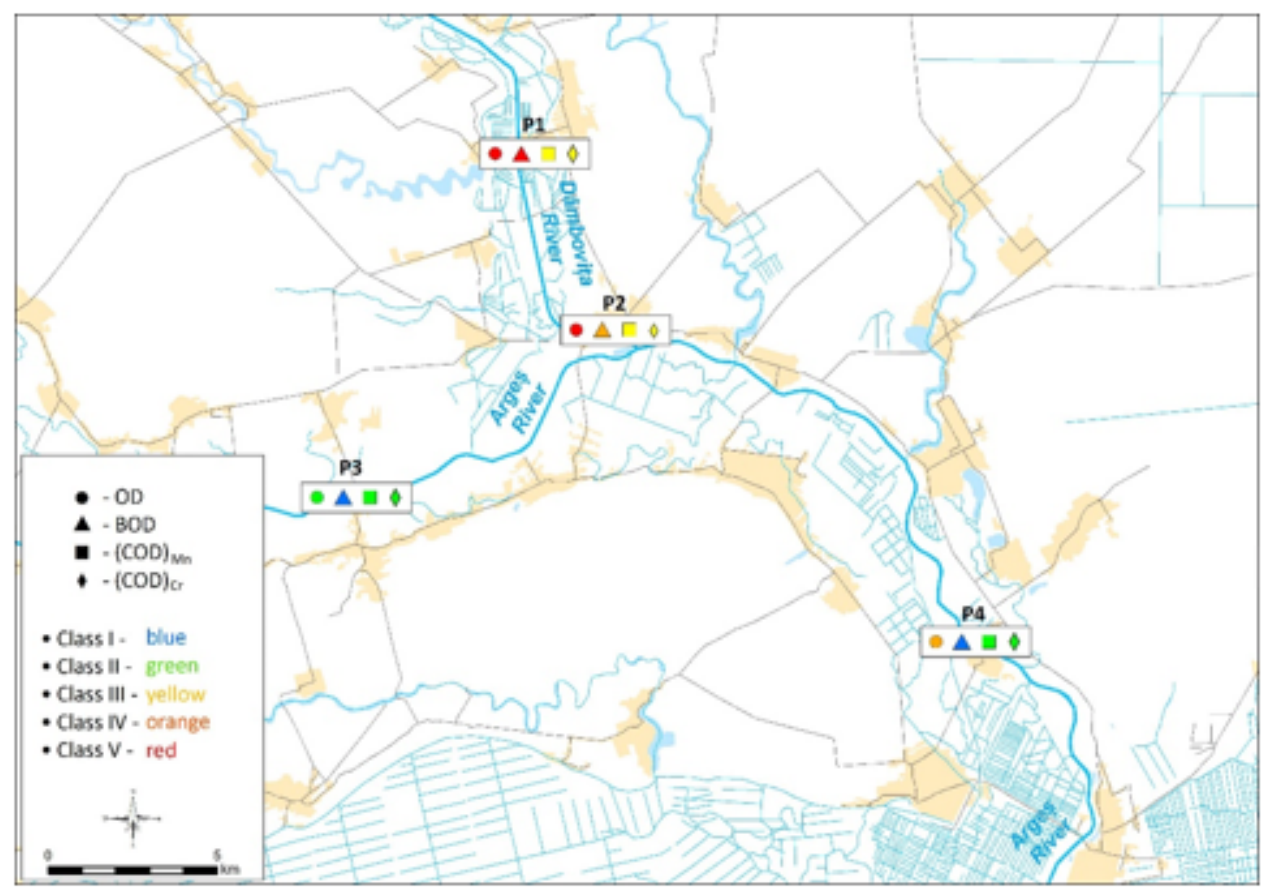

Fig. 2. Water quality classes for the indicators $\mathrm{DO}, \mathrm{COD}_{\mathrm{Cr}^{\prime}} \mathrm{COD}_{\mathrm{Mn}}$ and BOD geo-referenced for each sampling location

$\mathrm{mgO}_{2} / \mathrm{L}(\mathrm{P} 1) ; \mathrm{COD}_{4}$ values varied between $6.94 \mathrm{mgO} / \mathrm{L}$ (P3) $-19.95 \mathrm{mgO} / \mathrm{L}(\mathrm{P} 1)$ and $\mathrm{BOD}$ values recorded a minimum of $2.06 \mathrm{mgO}_{2} / \mathrm{L}$ (P3) and a maximum of 31.02 $\mathrm{mgO} / \mathrm{L}(\mathrm{P} 1)$.

From figure 2 it can be noticed that in the case of two sampling locations P1 and P2 established for the Dambovita River the DO values have been included in the water quality Class V and the COD $\left(C_{C O D}\right.$ and $\left.C O D_{M n}\right)$ values in water quality Class III. The BOD values obtained were classified as quality Class V for P1 and Class IV for $P 2$. In the case of sampling locations established for the Arges River (P3 and P4), the DO values were included in water quality Class II for P3 and IV for P4, the BOD values were included in water quality Class I for the both locations and also the $C O D_{r r}$ and $C O D_{M n}$ values were included in water quality Class'll for both locations.

Figure 3 shows the water quality classes according to their values obtained for the quality indicators of nutrients regime. The values obtained for $\mathrm{NH}-\mathrm{N}$ ranged from 0.10 $\mathrm{mg} / \mathrm{L}(\mathrm{P} 3)$ to $9.17 \mathrm{mg} / \mathrm{L}(\mathrm{P} 1)$, the $\mathrm{NO}_{3}-\mathrm{N}$ values determined in the four sampling locations ranged from $0.03 \mathrm{mg} / \mathrm{L}$ (P2) to $0.49 \mathrm{mg} / \mathrm{L}$ (P3) and the TN values varied between 1.49 $\mathrm{mg} / \mathrm{L}$ (P3) and $10.49 \mathrm{mg} / \mathrm{L}$ (P1). Regarding the values recorded for $\mathrm{PO}_{4}-\mathrm{P}$ and $\mathrm{TP}$, these were in the range of 0.05 $\mathrm{mg} / \mathrm{L}(\mathrm{P} 2)-0.73^{4} \mathrm{mg} / \mathrm{L}(\mathrm{P} 1)$, respectively $0.22 \mathrm{mg} / \mathrm{L}$ (P3) $1.20 \mathrm{mg} / \mathrm{L}(\mathrm{P} 1)$. The values obtained for Chlorophyll a ranged from $2.37 \mathrm{mg} / \mathrm{L}$ (P3) to $15.04 \mathrm{mg} / \mathrm{L}$ (P1).

From figure 3 itcan be seen that for $\mathrm{P} 1$ and $\mathrm{P} 2$ sampling locations on Dambovita River, the values obtained for the quality indicators of the nutrients regime have led to similar quality classes for the two selected locations. Thus, for both sections, the $\mathrm{NH}-\mathrm{N}$ recorded values were specific to water quality Class $\mathrm{V}^{4} \mathrm{NO}_{2}-\mathrm{N}$ values to quality Class III, TP values to quality Class II and the $\mathrm{NO}_{3}-\mathrm{N}$ and Chlorophyll a values to water quality Class I.

In the case of water samples collected from P3 and P4, locations situated on the Arges River, values belonging to water quality Class I for $\mathrm{NO}_{3}-\mathrm{N}$, TN, Chlorophyll a were observed in both locations, values specific to the water quality Class IV for $\mathrm{NH}_{4}-\mathrm{N}$ and $\mathrm{NO}_{2}-\mathrm{N}$ in P4, values for quality Class III for $\mathrm{NO}_{2}-\mathrm{N}$ and water quality Class I for $\mathrm{NH}_{4}-\mathrm{N}$ in P3. The ammonium ion presence in a higher amount in the analysed samples from P4 may be due to the organic substances decomposition under anaerobic conditions and

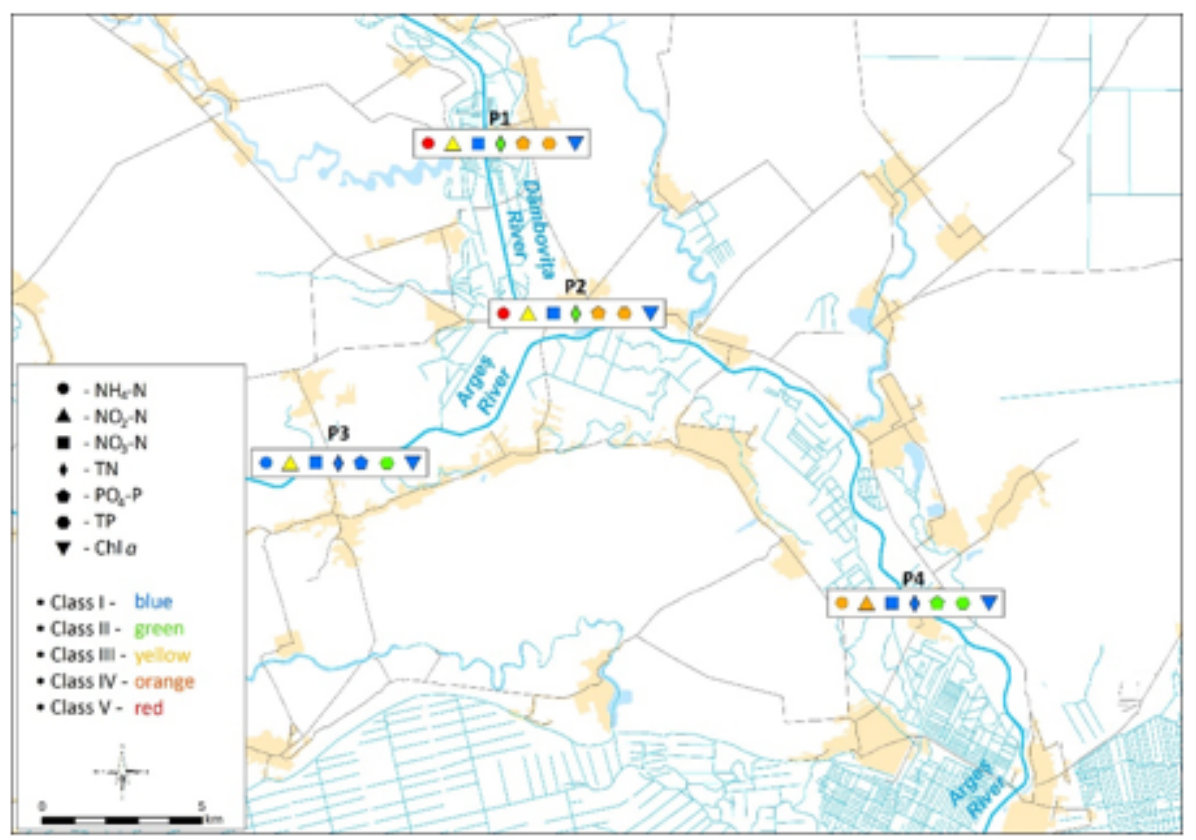

Fig. 3. Water quality classes derived from nutrients geo-referenced for each sampling location 


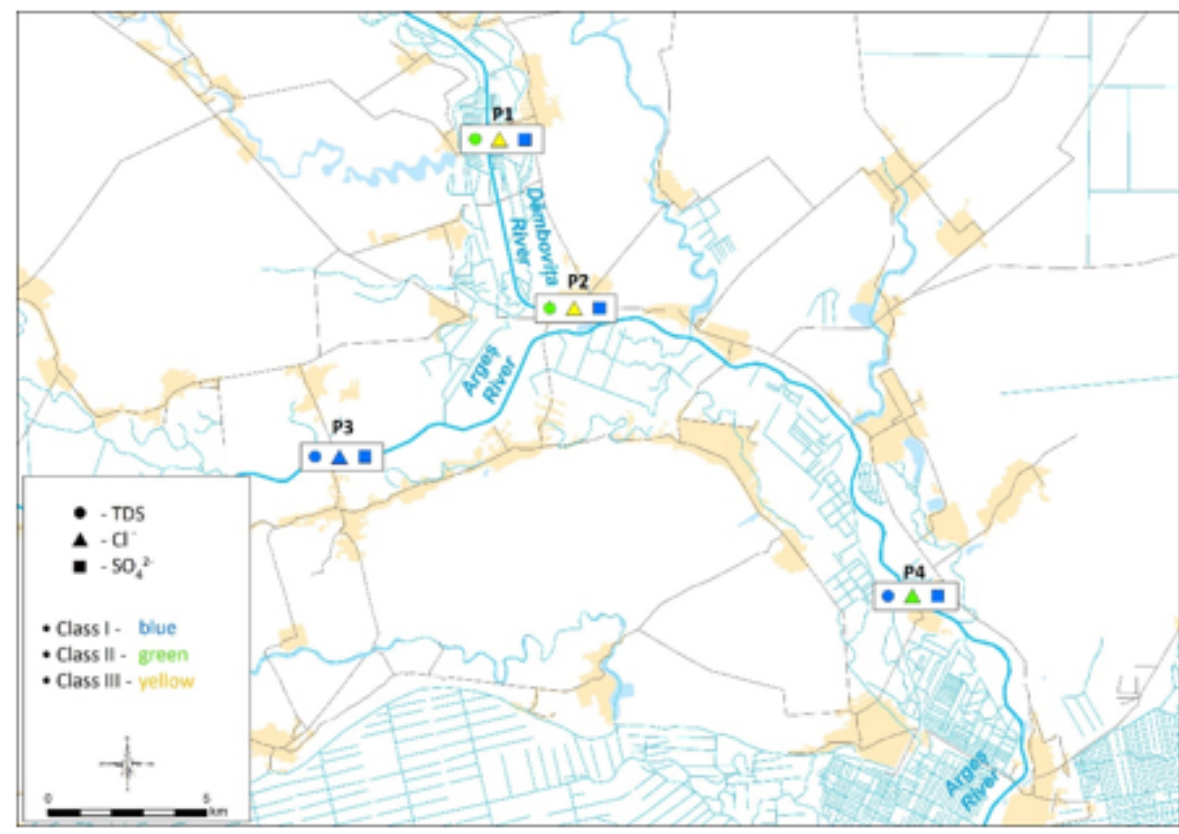

Fig. 4. Water quality classes for Salinity geo-referenced for each sampling location

in the presence of bacteria or reduction of nitrate ions. For locations situated on the Arges River, the TP and $\mathrm{PO}_{-}-\mathrm{P}$ values obtained in $\mathrm{P} 3$ were specific to water quality Class I and for P4 were specific to quality Class I and Class II.

Regarding the salinity specific quality indicators, EC values ranged from $704 \mu \mathrm{S} / \mathrm{cm}$ (P1) to $355 \mu \mathrm{S} / \mathrm{cm}$ (P3), TDS values from $266 \mathrm{mg} / \mathrm{L}$ (P3) to $528 \mathrm{mg} / \mathrm{L}$ (P1), Cl values varied in the range of $17.5 \mathrm{mg} / \mathrm{L}(\mathrm{P} 3)-63 \mathrm{mg} / \mathrm{L}(\mathrm{P} 1)$ and $\mathrm{SO}_{4}{ }^{2-}$ values ranged from $37.61 \mathrm{mg} / \mathrm{L}(\mathrm{P} 3)$ to $45.57 \mathrm{mg} / \mathrm{L}$ (P1). The high values of conductivity are an indicator of high concentrations of dissolved ions in water. Figure 4 shows the water quality classes for TDS, $\mathrm{Cl}^{-}$and $\mathrm{SO}_{4}^{22}$.

From figure 4 it can be noticed that for the sampling locations situated on the Dambovita River, the obtained values were included in similar water quality classes for both locations, as follows: the TDS values were specific to the quality Class II of water, the $\mathrm{Cl}^{-}$values were specific to quality Class III and $\mathrm{SO}_{4}^{2-}$ values to quality Class I. In the case of samples collected from Arges River, the TDS and $\mathrm{SO}^{2-}$ values were in the water quality Class I for both locations and the $\mathrm{Cl}$-values were in the quality Class I in $\mathrm{P} 3$ and quality Class II in P4.

For the water samples collected from the four monitoring locations, the following heavy metals have been analysed: $\mathrm{Cd}, \mathrm{Pb}$ and $\mathrm{Cu}$. After evaluation of the values obtained we observed the following aspects: the $C d$ values ranged between $0.04 \mathrm{~g} / \mathrm{L}$ in $\mathrm{P} 1$ and to below the method detection limit, respectively $0.02 \mathrm{mg} / \mathrm{L}$ for $\mathrm{P} 2, \mathrm{P} 3$ and $\mathrm{P} 4$, the $\mathrm{Pb}$ values ranged between $1.98 \mathrm{~g} / \mathrm{L}$ in $\mathrm{P} 1$ and to below the method detection limit, respectively $0.30 \mu \mathrm{g} / \mathrm{L}$ in $\mathrm{P} 3$ and $\mathrm{Cu}$ values varied between $4.88 \mu \mathrm{g} / \mathrm{L}$ in $\mathrm{P} 1$ to $1.70 \mu \mathrm{g} / \mathrm{L}$ in P4.

Figure 5 shows the variation of the heavy metal concentrations determined in water samples. Following the reporting of the heavy metals values obtained to the current national regulations, the classification in water quality Class I for all the values has been obtained.

\section{Assessment of sediment quality}

For the sediment quality assessment the following heavy metals have been analysed: $\mathrm{Cd}, \mathrm{Hg}, \mathrm{Cr}, \mathrm{Cu}, \mathrm{Ni}, \mathrm{Zn}$ and $\mathrm{Pb}$. Figures 6-9 show the variation of heavy metal concentration $(\mathrm{mg} / \mathrm{kg})$ in the sediment samples for each sampling locations.

After the assessment of heavy metal concentrations the values obtained for the determined heavy metals have

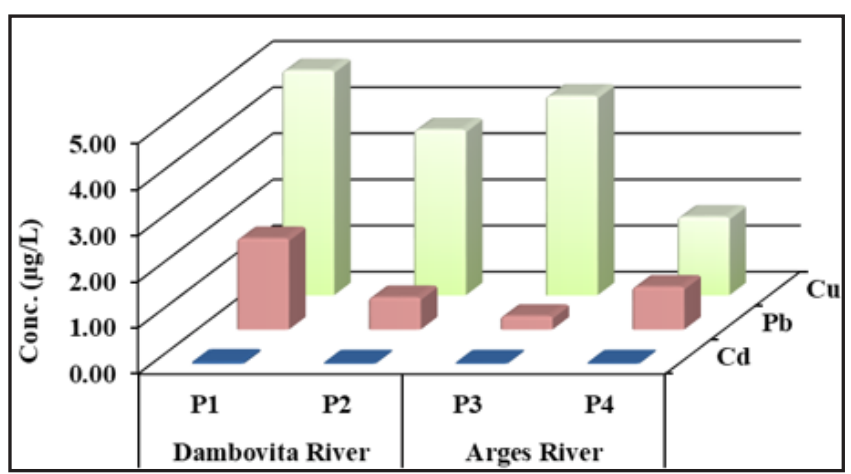

Fig. 5. The concentration of heavy metals $\mathrm{Cd}, \mathrm{Pb}$ and $\mathrm{Cu}$ determined in water samples

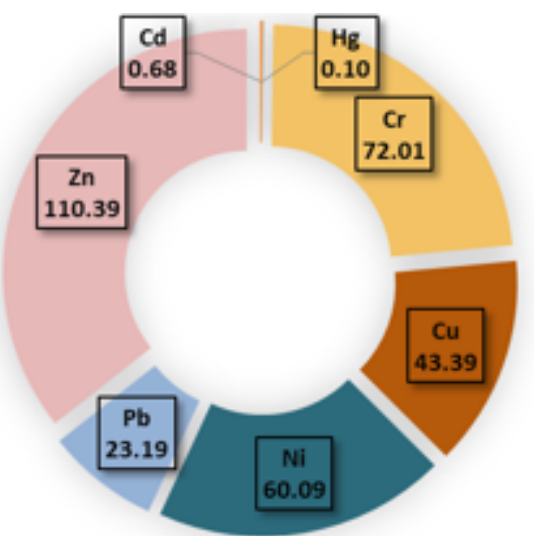

Fig. 6. The concentration of heavy metals in sediment samples in $\mathrm{P} 1$

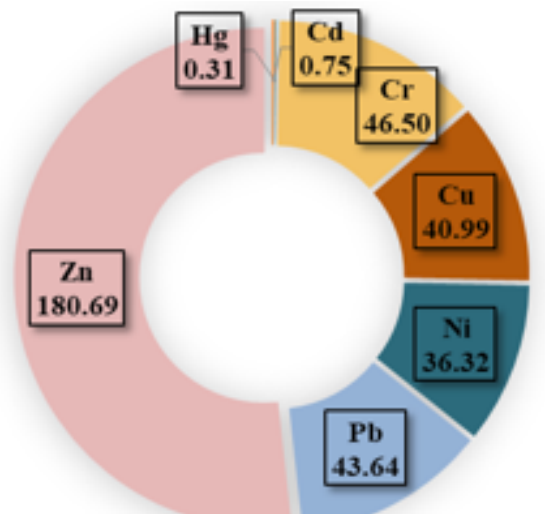

Fig. 7. The concentration of heavy metals in sediment samples in $\mathrm{P} 2$ 


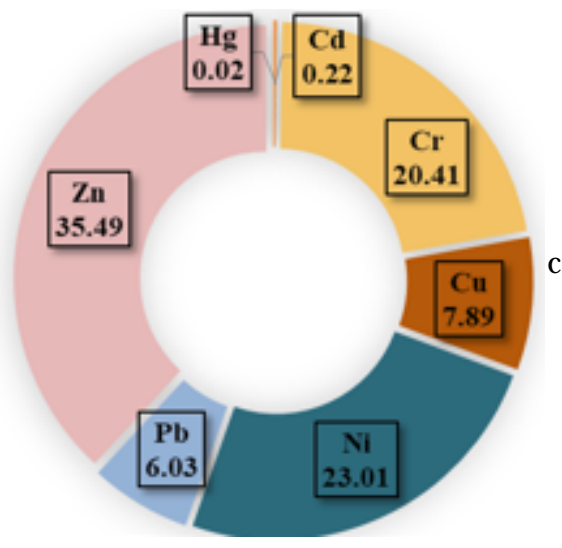

Fig. 8. The concentration of heavy metals in sediment samples in P3

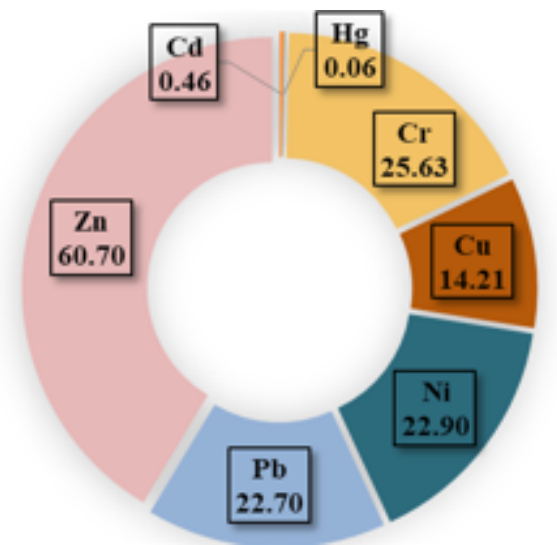

Fig. 9. The concentration of heavy metals in sediment samples in P4
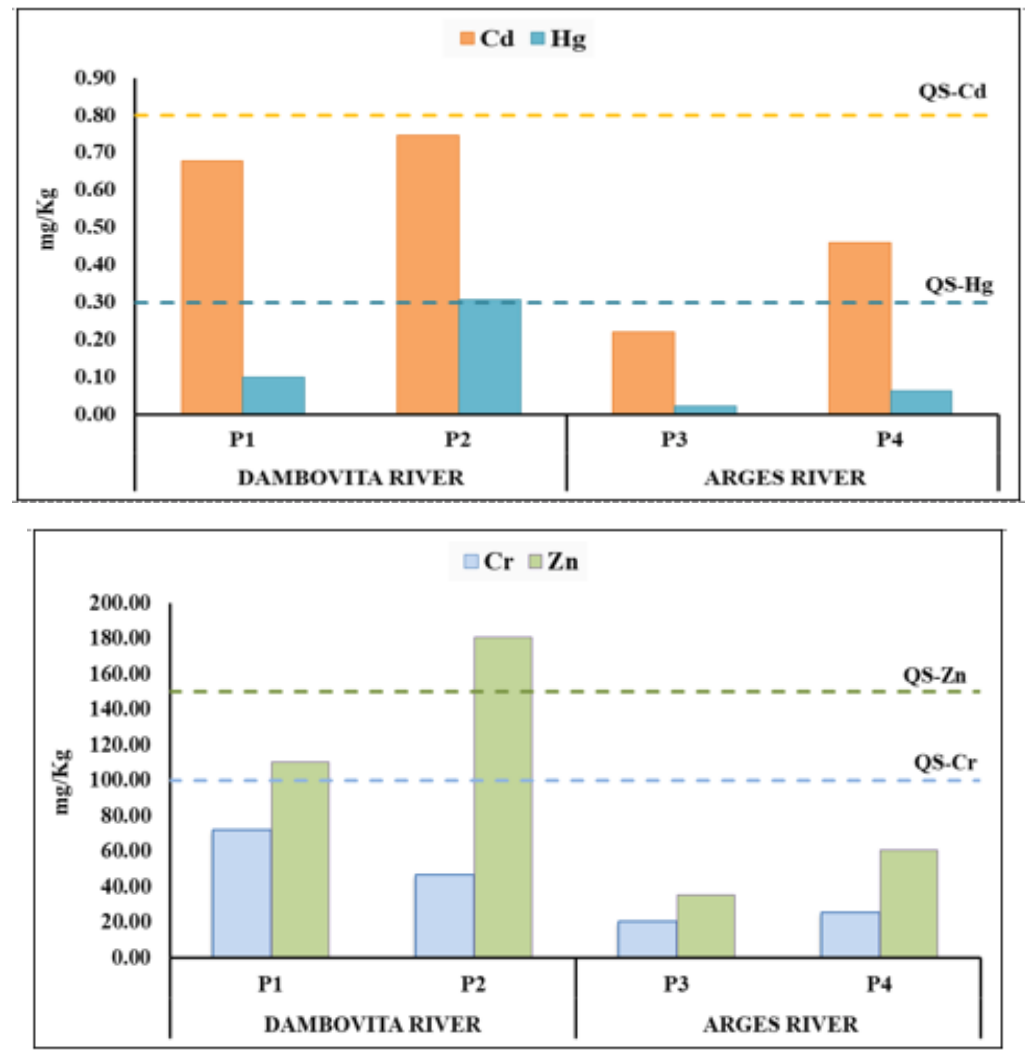

Fig. 10. The concentration of $\mathrm{Cd}$ and $\mathrm{Hg}$ in sediment samples compared to chemical quality standards

Fig. 11. The concentration of $\mathrm{Cr}$ and $\mathrm{Zn}$ in sediment samples compared to chemical quality standards

Fig. 12. The concentration of $\mathrm{Cu}, \mathrm{Ni}$ and $\mathrm{Pb}$ in sediment samples compared to chemical quality standards

varied in order: $\mathrm{Zn}>\mathrm{Cr}>\mathrm{Ni}>\mathrm{Cu}>\mathrm{Pb}>\mathrm{Cd}>\mathrm{Hg}$ in $\mathrm{P} 1$ (fig. 6), $\mathrm{Zn}>\mathrm{Cr}>\mathrm{Pb}>\mathrm{Cu}>\mathrm{Ni}>\mathrm{Cd}>\mathrm{Hg}$ in P2 (fig. 7), $\mathrm{Zn}>\mathrm{Ni}>\mathrm{Cr}>\mathrm{Cu}>\mathrm{Pb}>\mathrm{Cd}>\mathrm{Hg}$ in $\mathrm{P3}$ (fig. 8) and $\mathrm{Zn}>\mathrm{Cr}>\mathrm{Ni}>\mathrm{Pb}>\mathrm{Cu}>\mathrm{Cd}>\mathrm{Hg}$ in $\mathrm{P} 4$ (fig. 9). It has been observed that in P1, P3 and P4, heavy metals $\mathrm{Zn}, \mathrm{Cr}$, Ni showed a high concentration, and in $\mathrm{P} 2, \mathrm{Zn}, \mathrm{Cr}$ and $\mathrm{Pb}$ recorded high values. Figures 10-12 show the framing of heavy metal concentrations determined in the sediment samples in chemical quality standards (QS) according to national regulations [22].

From analyzing the graphs presented above in figures 10-12, the values for $\mathrm{Cd}$ and $\mathrm{Hg}$ were highlighted below 3642 the limits of the chemical quality standards, respectively $\mathrm{QS}-\mathrm{Cd}=0.8 \mathrm{mg} / \mathrm{Kg}$ and QS-Hg $=0.3 \mathrm{mg} / \mathrm{Kg}$ (fig. 10). Also, the values obtained for $\mathrm{Cr}$ were below the chemical quality standards (QS-Cr $=100 \mathrm{mg} / \mathrm{Kg}$ ) while Zn recorded slightly higher values only in P2 compared to the quality standard (QS-Zn $=150 \mathrm{mg} / \mathrm{Kg}$ ) (fig. 11). The values obtained for $\mathrm{Pb}$ were below the chemical quality standards (QS-Pb $=85$ $\mathrm{mg} / \mathrm{Kg}$ ), while the concentrations obtained for $\mathrm{Cu}$ and $\mathrm{Ni}$ recorded slight exceedances in $\mathrm{P} 1$ and $\mathrm{P} 2$ compared to the reference standards ( QS-Cu $=40 \mathrm{mg} / \mathrm{Kg}$; QS-Ni $=35$ $\mathrm{mg} / \mathrm{Kg}$ ) (fig. 12). 


\section{Conclusions}

The quality of freshwater resources, respectively of the Arges and Dambovita Rivers, has been assessed at their confluence area using physicochemical parameters according to the national regulations. Following the analyses carried out for the water samples collected from the two sampling locations on the Dambovita River, specific values of water quality Class $V$ for organic substances and nutrients have been highlighted at locations Dambovita/Nuci and Dambovita/Budesti. Also, for the sediment samples slight exceedances have been highlighted according to the chemical quality standards for $\mathrm{Cu}$, Ni in location Dambovita/Nuci and Ni, Zn in location Dambovita/Budesti, with the possibility of developing some minor pressure from these indicators on the studied freshwater resources.

Regarding the Arges River, the analyses revealed that from the physicochemical point of view, downstream of Budesti after the river receives the polluted waters of the Dambovita River at Clatesti, the water quality changes to quality Class IV, due to the presence of organic substances and nutrients. Pollution by organic substances and nutrients may be due to emissions/discharges of wastewater from the Bucharest sewage system, as a result of the incapacity of the Glina treatment plant to take over the total volume of wastewater collected, some of the wastewater collected through the sewerage system being discharged into the Dambovita River. Also, along with this, some other possible pollution sources such as human agglomerations, discharges from economic agents, agricultural land leakage, uncontrolled waste deposits on the banks and riverbeds located upstream and downstream of the sewage treatment plant Glina can be considered.

In view of the data obtained for the water quality assessment of Dambovita River where high nutrient values, especially the nitrite concentrations were recorded, it can be concluded that the water quality of Dambovita River, in addition to those mentioned above, is influenced by the water quality of its tributary, the Colentina River which flows into it downstream of Bucharest.

This work provides basic information on the pollution status of the two rivers that are important sources as freshwater resources for residents of Bucharest and from the surrounding areas, therefore, frequent and systematic water quality monitoring is necessary in order to protect public health and improve the quality of life.

Acknowledgements. This work used data obtained through the MARES 43N/2018, project PN 18260102. The authors would like to thank the management and employees of National Institute for Research and Development in Environmental Protection for their valuable assistance and suggestions. Petra lonescu's contribution was partially financed by the Operational Programme Human Capital of the Ministry of European Funds through the Financial Agreement51668/09.07.2019, SMIS code 124705.

\section{References}

1. IONESCU, P., RADU, V.-M., DEAK, Gy., DIACU, E., MARCU E., CIOBOTARU I.-E., Rev. Chim. (Bucharest), 70, no. 8, 2019, p. 2889. 2.LAZAR, I.G., DIACU E., VASILE, G.G., UNGUREANU, E.M., IVANOV, A.A., Rev. Chim. (Bucharest), 69, no. 9, 2018, p. 2311.
3.PAUN, I., CHIRIAC, F.L., MARIN, N.M., CRUCERU, L.V., PASCU, L.F., LEHR, C.B., ENE, C., Rev. Chim. (Bucharest), 68, no. 8, 2017, p.1732. 4.MILACIC, R., ZULIANI, T., VIDMAR, J., OPRCKAL P., SCANCAR, J., Science of the Total Environment, 605-606, 2017, p. 894.

5.FADER, M., S. SHI, S., VON BLOH, W., BONDEAU, A., CRAMER, W., Hydrol. Earth Syst. Sci., 20, 2016, p. 953.

6.WU, Z., WANG, X., CHEN, Y., CAl, Y., DENG, J., Science of the Total Environment, 612, 2018, p. 914.

7.RADU, V.-M., DIACU, E., MONCEA, M.A., DUMITRU, F.D., PANAIT, A.M., IONESCU, P., Rev. Chim. (Bucharest), 68, no. 11, 2017, p. 2477. 8.RADU, V.M, IONESCU, P., DIACU, E., IVANOV, A.A., Rev. Chim. (Bucharest), 68, no. 12, 2017, p. 2765.

9.FATHI, E., ZAMANI AHMADMAHMOODI, R., ZARE BIDAKI, R., Applied Water Science, 8, no. 210, 2018, https://doi.org/10.1007/s13201-0180859-7.

10.NIKOO, M.R., KERACHIAN, R., MALAKPOUR-ESTALAKI, S., BASHIAZGHADI, S.N., AZIMI-GHADIKOLAEE, M.M., Environmental Monitoring and Assessment, 181, no.1-4, 2011, p. 465.

11.MARCU, E., DEAK, Gy., CIOBOTARU, I.-E., IVANOV, A. A., IONESCU, P., TOCIU, C., DIACU, E., Rev. Chim. (Bucharest), 68, no. 11, 2017 p. 2492.

12.DEAK, Gy., DAESCU, V., HOLBAN, E., MARINESCU, P., TANASE G.S., CSERGO, R., DAESCU, A.I., GAMAN, G., J ournal of Environmental Protection and Ecology, 16, no. 1, 2015, p. 304.

13.GREEN, A.J., PLANCHART, A., Comparative Biochemistry and Physiology Part C: Toxicology \& Pharmacology, 208, 2018, p. 12.

14.MILOSKOVIC, A., MILOSEVIC, D., RADOJ KOVIC, N., RADENKOVIC, M., ĐURETANOVIC, S., VELICKOVIC, T., SIMIC, V., Science of the Total Environment, 644, 2018, p. 899.

15.YILMAZ, A.B, YANAR, A., ALKAN, E.N., Pollution, 4, no. 1, 2018, p. 143.

16.ARCHER, E., PETRIE, B., KASPRZYK-HORDERN, B., WOLFAARDT, G.M., Chemosphere, 174, 2017, p. 437.

17.GEISSEN, V., MOL, H., KLUMPP, E., UMLAUF, G., NADAL, M., VAN DER PLOEG, M., VAN DE ZEE, S.E.A.T.M., RITSEMA, C.J., International Soil and Water Conservation Research, 3, 2015, p. 57.

18.GHASEMI, S., MOGHADDAM, S.S., AMIR RAHIMI, A., DAMALAS C.A., NAJI, A., Chemosphere, 191, 2018, p. 417.

19.COCOS, O., Managementul apei în Municipiul Bucuresti, Editura Ars Docendi, 2006, pp 68-69.

20.ZAHARIA, L., TOROIMAC, G.I., COCOS, O., GHITA, F.A., MAILAT, E., Ecosystem Health and Sustainability, 2, no. 11, 2016, DOI: 10.1002/ ehs2.1247.

$21{ }^{* * *}$ Directive 2000/60/EC of the European Parliament and of the Council establishing a framework for the Community action in the field of water policy.

22.***Ministerial Order No. 161/2006 for the Approval of the Norm Concerning the Reference Objectives for the Surface Water Quality Classification (Including Quality Standards for Sediments).

23.***EN ISO 5667-1:2007, Water quality. Sampling. Part 1: Guidance on the design of sampling programmes and sampling techniques. 24.***EN ISO 5667-3:2013, Water quality. Sampling. Part 3: Preservation and handling of water samples.

25.***EN ISO 5667-6:2017, Water quality. Sampling. Part 6: Guidance on sampling of rivers and streams.

26.***EN ISO 5667-12:2017, Water quality. Sampling. Part 12: Guidance on sampling of bottom sediments from rivers, lakes and estuarine areas

Manuscript received: 17.01 .2019 